\title{
MANDATORY UnISEX POLICIES AND ANNUITY PRICING: QUASI-EXPERIMENTAL EVIDENCE FROM GERMANY
}

Hans-Martin von Gaudecker

and

Carsten Weber

( ) Mea-Mannheim Research Institute for the Economics of Aging

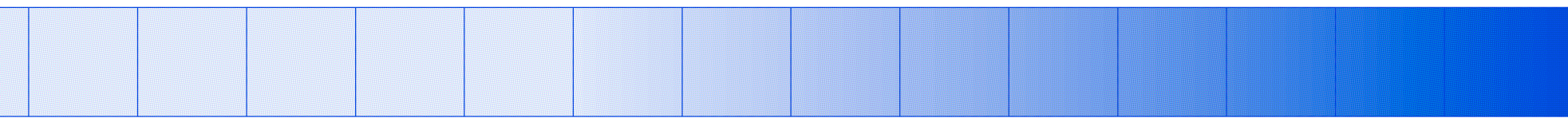

L13, 17_D-68131 Mannheim_Phone +49 621 181-2773/1862_Fax +49 621 181-1863_www.mea.uni-mannheim.de 


\title{
Mandatory Unisex Policies and Annuity Pricing: Quasi-Experimental Evidence from Germany*
}

\author{
Hans-Martin von Gaudecker ${ }^{\dagger}$ \\ Mannheim Research Institute for the Economics of Aging (MEA), Universität Mannheim \\ Carsten Weber \\ Chair of Risk Theory, Portfolio Management and Insurance, Universität Mannheim ${ }^{\ddagger}$
}

October 9, 2006

\begin{abstract}
We analyse the effect of abolishing gender-based categorisation of risks on the pricing of annuity contracts. Under the absence of screening activities, we find clear evidence of insurers expecting strong adverse selection effects. In particular, most of the unisex contracts' payouts closely resemble those from women's policies before the reform. Hence the policy target is not met and there are large efficiency losses for men. We conclude that there seems to be little hope for unisex policies to meet their equity objectives if consumers can react on the extensive margin, unless subsidies are extremely large.
\end{abstract}

\section{Introduction}

The payout phase of third pillar pension arrangements has received considerable attention in recent years. Most models from economic theory suggest annuities to be the most important decumulation instrument. However, empirical studies frequently find very low degrees of annuitisation (Mitchell, Poterba, Warshawsky, and Brown 1999). High loading charges by insurers are often quoted as a prime reason for this finding. A means of making annuities more attractive are government-subsidised retirement savings plans that require annuitisation. Germany introduced such a scheme in 2001 (Börsch-Supan and Wilke 2004).

Having been introduced with the intention to create a substitute for first pillar pensions, the issue of categorical discrimination has received special attention in this market. Since the only important characteristic used in pricing was gender, its critics have argued that the reform was disadvantageous to women. They tend to be longer-lived than men and thus received a lower monthly pension for a given premium, contrary to first pillar pensions. Others have argued on efficiency grounds, claiming that the abolishment of categorising risks would lead to lower participation in the market by high mortality persons. Finally the first side enforced their view and gender-based pricing was abolished as of the beginning of 2006 .

\footnotetext{
*We would like to thank Morgen \& Morgen GmbH for letting us use a reduced fee license of their insurance broker software as well as Holger Bartel and Herbert Schneidemann of the German Insurance Association for supplying us with an electronic version of the DAV 2004R life tables. We appreciate helpful comments on early versions of this paper from seminar participants at Mannheim University and the German Insurance Association in Berlin. Daniel Kemptner provided able research assistance.

$\dagger$ Address for correspondence: Mannheim Research Institute for the Economics of Aging; L 13, 17; 68131 Mannheim; Germany. Email: gaudecker@mea.uni-mannheim.de

$\ddagger$ Carsten Weber joined BASF AG after completing this work.
} 
In this paper, we study the impact of this law change on the payouts of annuities. The setup allows us to assess the degree of adverse selection that insurance companies expect. To the best of our knowledge, this is the first study to perform such an analysis in the annuities market, whereas several recent papers have examined the effects of related bans in the health insurance market (Buchmueller and DiNardo (2002), Simon (2005), Herring and Pauly (2006)). An obvious advantage of looking at annuities markets is the virtual absence of moral hazard problems (Finkelstein and Poterba 2004). A disadvantage of this is that policy reforms do not lend themselves easily to micro-data analyses. The reason for this is that signing a contract and committing to contribute on a monthly basis is largely a once and for all decision. In the previously mentioned analyses new health insurance contracts have to be signed every period. Forward-looking good risks may anticipate the reform and buy a contract before the ban which will not be affected. ${ }^{1}$ In such a situation, neither differential rates of take-up nor differences in contract holdings (even if contract characteristics were known) would tell much about the reform's impact. However, an analysis of pricing and hence insurers' expectations may reveal a lot about efficiency costs associated with the reform.

This is all the more the case since in the market under study, regulations on the structure of annuity contracts are very tight. Hence insurers' possibilities to engage in screening activities through contract design seem to be very limited. In particular, pensions may not fall over time. This eliminates the contract feature that is found out to be the most important screening mechanism in Finkelstein, Poterba, and Rothschild (2006), namely a sharp drop in pension payments towards the end of the life-span in the contract designed for the "good risks" (i.e. high mortality types). In practice, no firm offers more plans under unisex pricing than before. Hence we cannot detect any screening activities. Efficiency costs then are solely associated with (expected) reactions on the extensive margin. While this setup is not very interesting from an economic theory perspective, it provides an interesting contrast to the analysis of Finkelstein, Poterba, and Rothschild (2006) where participation in the market was taken as given and contract design was more flexible.

Our results indicate that before the reform signing a government-sponsored contract was highly attractive for both sexes. In particular, due to the subsidy loading charges were actually negative for the annuitant population. The reform leads to a uniform pricing that is virtually identical to female contracts before the reform. Hence, the new situation is almost a worsening in the Pareto sense. Women find themselves only slightly better off while men could either not participate in the market or sign a contract to much less favourable conditions with payouts that are about seven percent lower than before.

This note is structured as follows. The next section describes the situation before the reform. Part 3 is the central part of the analysis and describes the impact of the law change. Finally, section 4 contains a discussion of the findings and concludes. Assumptions employed in the money's worth ratio calculations can be found in the appendix.

\footnotetext{
${ }^{1}$ Anecdotal evidence indeed does suggest a rally of sales to men in late 2005. Unfortunately no official figures are available beyond aggregate statistics which do not discriminate by gender.
} 


\section{Subsidised Retirement Savings in Germany}

In recent years, several major pension reforms have started to transform the monolithic Bismarckian system of Germany into a complex multipillar one. In this paper we are particularly concerned with the 2001 "Riester reform", named after the then minister of labour Walter Riester and described in detail by Börsch-Supan and Wilke (2004). It introduced a direct savings subsidy for all dependently employed and certain self-employed persons. Alternatively, such savings can be deducted from taxable income up to a certain amount, which is advantageous for persons with a higher marginal tax rate. We do not consider this here because it would entail a modelling of the tax system which is beyond the scope of this paper and does not impact upon its main point. Still, it is useful to bear in mind that the subsidy constitutes a lower bound on actual retirement savings support by the government. We restrict our analysis to singles without children, those with children enjoy even higher subsidies or tax breaks.

Contracts eligible for government sponsoring have to fulfill an extensive list of criteria that is presented in BörschSupan and Wilke (2004). The most popular type of contract closely resembles the typical private annuity product as described in von Gaudecker and Weber (2004). By the end of 2005, the total number of such insurance policies sold had reached 4.4 million according to figures of the German Insurance Association. In December 2004, the male/female composition of contributions to these contracts was 60/40 percent (DAV 2005b).

Annuity payments are made up of a fixed and a variable component. The fixed component is guaranteed by the insurer, hence it bears all investment and demographic risk up to this point. The variable component is determined in a complex manner by the overall surplus earned by the insurance company through the so-called profit sharing rate. This may vary annually and the resulting variable component can either be added to the guaranteed part ("constant participation scheme") or itself be annuitised ("escalating participation scheme"). We only consider the latter scheme in this note because of its greater availability. For the same reason we report statistics only on 10 years period certain annuities. Conclusions do not change for no period certain annuities and we omit them for brevity reasons. ${ }^{2}$ Tables are available from the authors upon request.

We look at persons from the 1956 cohort because this is the oldest one for which all insurance companies active in the market (28) offer pension plans under the subsidised scheme. Upon retirement, the exemplary person detailed in Appendix A will have paid in 15,866 Euros. The government subsidy will have amounted to an additional 2,230 Euros (both figures are in nominal terms). The first column of Table 1 lists the guaranteed payoffs based on the individual contributions only. ${ }^{3}$ The mean payouts do not have much of an interpretation at this point. However, we note considerable heterogeneity among firms: The difference from the lowest offer to the highest is well more than ten percent, the inter-quartile range is still more than five percent. This resembles earlier findings reported by von Gaudecker and Weber (2004) for Germany; Mitchell and McCarthy (2002) for the US; and James and Vittas (2000) in a cross-country survey.

Table 2 shows similar statistics for the estimated pension in the first year. Mean payouts are not directly compa-

\footnotetext{
${ }^{2}$ Note that the participation scheme and the length of the certain payment period would be the only ways of how firms may engage in screening activities. See Finkelstein and Poterba (2004) for a related point. However, payout adjustments for plans that differ across these dimensions are similar and we cannot detect any attempt to screen customers.

${ }^{3}$ Note that this number does not have too much relevance for individual decision-making: The government subsidy is neglected and profit sharing rates can be expected to remain positive. However, it gives us a more convenient measure than the projected total payments because the ceteris paribus condition over 2005/2006 contracts is more likely to be fulfilled.
} 
rable to those from Table 1 because contributions now entail the government subsidy. If that is excluded, it becomes evident that the guaranteed pension is about two thirds of the total pension. This is less than figures reported in von Gaudecker and Weber (2004) because of the longer accumulation period compared to a single premium immediate annuity: Much depends on the surplus of the insurer during these fifteen years. Payout differences here amount to twenty percent of the mean annuity, the lowest and highest quartile differ by about ten percent. The explanation for these differences that would have been most comforting for economists, namely a trade-off between guaranteed and variable part of the annuities, does not go through. Correlations between both shares or the guaranteed part and profit sharing rates are either positive or very close to zero. These policies do not differ on any other characteristics and their coexistence can be interpreted as a sign of low price sensitivity among consumers.

In terms of value for money, the predominant and most simple concept in the literature is the Money's Worth Ratio (MWR), described in detail by Mitchell, Poterba, Warshawsky, and Brown (1999). It is essentially the ratio of (appropriately discounted) expected payouts and premia. An actuarially fair annuity has a MWR of one and a risk-neutral agent would be just on the margin of buying. Taking risk aversion into account, a typical economic agent values annuities much higher (Mitchell, Poterba, Warshawsky, and Brown 1999).

The first column of Table 3 shows the mean Money's Worth Ratio over all contracts offered in the market. This is based on own contributions only and excludes the government subsidy. Hence it reflects the numbers relating to the individual decision problem of whether or not to participate in the subsidised third tier plans. For reasons explained above, we ignore possible additional tax advantages. The MWRs of slightly above one for the annuitant population indicate that the state subsidy is just enough to offset loading charges for this group, on which insurers' calculations are based. For the general population, MWRs are still above ninety percent making such policies attractive for even moderately risk-averse agents. Active (through private information about one's health status) and passive (through socio-economic status considerations) adverse selection effects reinforce this argument - the group that is most likely to purchase such contracts can be expected to have a mortality that lies in between that of the population and that of people who purchased traditional private annuities. We conclude from these exercises that until 2005, subsidised annuity contracts were a very attractive investment opportunity for large parts of the German population. We now turn to the central part of this note, that is the effect of abolishing the possibility for gender-based pricing in this market.

\section{The Effect of Mandatory Unisex Policies on Annuity Payouts}

In July 2004, the German parliament passed a law that changed the eligibility criteria for government subsidies in one important aspect. In order to qualify for state sponsoring, annuity contracts were not allowed to discriminate by gender anymore if they were signed after December 2005. Hence we can compare contracts starting 1 January 2006 which are signed in December 2005 and contracts with the same starting date, but signature in January 2006. Doing so entails the assumption that all other parameters remain constant and we now argue that this is indeed the case for some key figures.

The law change did not directly affect any other characteristic of the subsidised savings scheme. In particular, all other criteria that determine eligibility for sponsoring remained the same, most importantly the requirement that 
payment streams may not fall over time. Hence companies did not have a chance to react along the lines analysed by Finkelstein, Poterba, and Rothschild (2006), namely a sharp reduction of payoffs for the designated low-risk contract towards the end of life. Indeed only one company continued to offer two types of contracts after the reform, one even withdrew its second type on 1 January 2006. Put briefly, we cannot detect any screening activities by firms. See also footnote 2 .

Besides the mortality assumptions, two parameters are relevant for the guaranteed pension payments listed in Table 1: The internal guaranteed interest rate and costs. The internal interest rate is restricted by law to be less or equal than $2.75 \%$. In private annuity markets, competition is thought to drive insurers to make use of this upper limit. We do not see any reason why this should be different in the market under consideration here unless profit sharing rates drop below this figure. The minimum observed rate, however, is $3.3 \%$ and this concern can be discarded. Costs are a different issue. They may change and we do not observe them. However, they are closely monitored by the German Federal Financial Supervisory Authority and large discretionary jumps are highly unlikely. ${ }^{4}$ If additional costs arise directly from the policy change (for example due to uncertainty about the gender composition in the contracts etc.) it should be included in the assessment of the change to unisex tariffs.

With respect to the estimated monthly pension upon retirement, this picture changes. Profit sharing rates play a major role here and mean figures did experience a slight drop from $4.46 \%$ to $4.39 \%$. More important is the considerable heterogeneity in the adjustment of profit sharing rates, which may blur the effect of the introduction of mandatory unisex tariffs. Hence we stick to adjustments of the guaranteed monthly pension payments for assessing the policy.

The key figures are contained in the second and third column of Table 1. Mean payouts for men suffer a substantial drop by 4.41 Euros (7.3\%) while they experience a slight rise for women (0.66 Euros or $1.2 \%)$. Hence most insurers seem to expect a very high percentage of women in the contracts. Once more heterogeneity among firms matters a lot: The difference in adjustments is up to six Euros for men and five Euros for women, reflecting very different expectations about the gender composition. By shopping around, customers could even gain more than before. The difference from the lowest to the highest provider is ten Euros or almost eighteen percent of mean guaranteed payouts. However, the bulk of insurers has similar expectations. The adjustments of fifty percent of all providers lie within 1.25 Euros of each other and their payments are not more than 3.25 Euros apart from each other, which constitutes no change as compared to the situation for contracts signed in 2005.

For completeness reasons, note that the adjustments to mean pension payments in the first year is similar to the one just described for guaranteed pensions (Table 2). However, the increased dispersion of guaranteed pensions is dominated by countervailing effects on profit sharing rates leading to a slight convergence of estimated monthly pension payments. As a consequence, Money's Worth Ratios drop substantially for men and do not change at all for women. This is evident from Table 3. Those for men are now roughly comparable to figures reported in von Gaudecker and Weber (2004) for traditional private annuities. This provides a rationale for companies to expect high

\footnotetext{
4Information on average costs is published mandatorily. It provides a good indicator for individual contracts' costs because the supervisory authority does not allow large differences between contracts within a firm. Unfortunately, no figures are available for 2006 yet. In 2004 the mean value was at $2.86 \%$ and it dropped by 0.11 percentage points (2.16\%) in 2005. Dispersion in this slight drop is low with the interquartile range at 0.1 percentage points. Changes of this magnitude would only have a negligible impact upon the analyses to follow.
} 
shares of women in the contracts: Men are very likely to prefer the more flexible private products with gender-based pricing, given that there seems to be little difference in terms of value for money.

\section{Discussion}

Our results indicate a nearly complete backfiring of the reform or more precisely almost a worsening of the situation in a Pareto sense. The question that arises naturally is whether they carry over to the long run and also to other situations.

A reason to expect higher payouts in the long run is the rally of sales to men in 2005 (see footnote 1). One could argue that most men who wanted to sign a "Riester-contract" over the next few years would have brought forward that decision, leaving the market saturated for a few years' time. On the other hand, if contracts are femaledominated after some years, it seems rather difficult to drive up male quotas (close) to parity levels. This argument is reinforced through the ready availability of close substitutes that are not eligible for government sponsoring. In the end, it all boils down to the size of the subsidy: If it is large enough to make government-sponsored products attractive for men even if pricing is based on female mortality, a true pooling equilibrium may well be achieved. If this is not the case, chances for this are meagre.

With respect to generalisability to other situations (such as a general ban on gender-based pricing for annuities), the substitute argument may be more disturbing. However, unless annuitisation is truly mandatory as in the case of government pensions with mandatory participation, substitutes will always exist. These include informal insurance within families (Post, Gründl, and Schmeiser 2006), fund withdrawal plans and the like. Another reason why one would not expect another finding in a more general context is the overall reluctance to buy annuities. If perceived loadings are an important reason for this, unisex prices would c.p. discourage men more from buying in the absence of subsidies. Adverse selection would then be reinforced.

We conclude from this that our finding with respect to insurers expecting strong adverse selection effects is likely to be valid in other situations as well. It follows that unisex policies have little justification on equity grounds in the private annuity context. This is all the more true in the light of large efficiency costs. The only ways that appear viable to achieve true pooling equilibria under unisex pricing seem to be mandatory participation or even larger subsidies than the ones granted by the German government under the "Riester-scheme".

\section{A Money's Worth Calculations and Assumptions}

The first part of this appendix briefly reviews the concept and calculation of the Money's Worth Ratio of individual annuities and presents our parameter assumptions. The most complicated parameters are the survival probabilities and the entire Section A.2 is devoted to their derivation. While we would like to analyse the simplest annuity product possible, that is single premium immediate annuities, we cannot do so because of the nature of subsidies during the accumulation phase. They are paid on a yearly basis to encourage regular savings and no single premium annuities are offered in the market. In fact, we have to go back to persons who are 50 years old in order to get a full coverage of the plans offered. We assume that they pay premia for fifteen years before retiring at the age of 
65. We neglect mortality in the accumulation phase because all savings are transferred to the saver's beneficiaries. Hence, pricing is not affected by differential mortality and the plans are similar to other savings instruments from an individual perspective.

\section{A.1 Money's Worth Formulas and Parameters}

The Money's Worth methodology is explained in detail in Mitchell, Poterba, Warshawsky, and Brown (1999), we just restate the formula in order to go through our parameter assumptions step by step:

$$
\mathrm{MWR}=\sum_{t=T_{0}}^{T_{R}-1} \frac{1}{\left(1+i_{t}\right)^{t} \cdot \text { Premium }_{t}} \cdot \sum_{t=T_{R}}^{\bar{T}} \frac{p_{t} \cdot \text { Pension }_{t}}{\left(1+i_{t}\right)^{t}}
$$

The unit of time is a month, the starting point $T_{0}$ of our analysis is 1 January 2006. Hence retirement takes place at $T_{R}=181$. The life tables end at the age of 120 and $\bar{T}=852$. We assume the interest rate $i$ to be flat at four percent throughout the analysed period and perform robustness checks by adding and subtracting 50 basis points. We chose this number because it resembles the yield of long-term German treasury bonds. The robustness checks did not produce new insights. We omit them here but we are happy to supply them upon request.

Premia were determined by the minimum amount that gives a person with median income the right to claim the maximum subsidy. From the German socio-economic panel we estimated annual median income to be 31,200 Euros for men between 45 and 55 years in 2004. We used this figure both for men and women, the program AV-Win then automatically calculates the contributions necessary to maximise the subsidy. The latter is phased in gradually and annual contributions needed are 822 Euros for 2006/2007 and 1,094 Euros from 2008 to 2020. In the first two years, the government subsidy amounts to 114 Euros. For the second period, it is at 154 Euros. Premia and subsidies were assumed to be paid annually on January 1 and stay constant over time. On the basis of these specifications, the monthly pension payments are calculated directly by the software AV-Win. We assume profit sharing rates to stay constant in the future which seems to be a conservative choice since today's rates are very low by historical standards.

\section{A.2 Life Tables}

The survival probabilities $p_{t}$ in equation (1) are obtained from the most recent life tables published by the German Actuaries' Society ("Deutsche Aktuarsvereinigung", DAV), referred to as "DAV 2004R" (DAV 2005a). These tables supply the reference mortality for annuity pricing in Germany since 2005.

The DAV 2004R tables consist of a period life table and a trend function that accounts for future mortality improvements. Both are constructed from data on annuitant mortality obtained from large reinsurance companies that is supplemented by population mortality published by the Federal Statistical Office and data from the German public pension insurance. In principle their derivation did not change much from the proceeding for the DAV $1994 \mathrm{R}$ tables, which is described in detail in von Gaudecker and Weber (2004). Improvements that are relevant here include the use of a more sophisticated trend function and the fact that they allow for a higher maximum age of 120 years. Furthermore, they explicitly take into account adverse selection at the point of retirement. We discard this effect 
because of the fact that only thirty percent of retirement wealth are allowed to be withdrawn under the subsidised savings scheme. For obvious reasons we exclude safety margins from the tables.

The 1999 baseline table takes into account adverse selection by containing much lower mortality rates than life tables for the general population. However, this is based on annuitant populations before the inception of the subsidised savings scheme. These are likely to be more selective in terms of socio-economic status than the ones targeted by the subsidies. Hence we also employ the most recent all-population mortality tables published by the Federal Statistical Office Germany (2006) as baseline tables for comparison purposes.

The trend function allows for two different trends in the short and in the long run. It has two free parameters which define the end of the short-run trend and the beginning of the (lower) long-run trend, respectively. Values in between are interpolated linearly. We chose 10 and 20 years for the trend function parameters as compared to the 1999 baseline table. This constitutes a middle ground of the range of values deemed reasonable in DAV (2005a). Furthermore, these parameters yield future life expectancies that are close to all-population estimates from other sources if combined with a population baseline life table.

Table 4 sketches the expected remaining lifetime at age 65 of the analysed cohort at their point of retirement in 2021. Obviously, women are expected to live longer and the additional lifetime comprises about three years and eight months independent of the mortality assumptions. Applying the DAV life tables, both sexes dispose of an increased expected remaining lifetime of about three years relative to all-population mortality.

\section{B Tables}

Table 1: Statistics on Guaranteed Monthly Pension Payments

\begin{tabular}{llrrr}
\hline \hline \multirow{2}{*}{ Mean } & Men & $60.34 \mathrm{EUR}$ & $55.93 \mathrm{EUR}$ & $-4.41 \mathrm{EUR}$ \\
& Women & $55.28 \mathrm{EUR}$ & $55.93 \mathrm{EUR}$ & $0.66 \mathrm{EUR}$ \\
\hline \multirow{2}{*}{ Max-Min } & Men & $7.00 \mathrm{EUR}$ & $10.00 \mathrm{EUR}$ & $6.00 \mathrm{EUR}$ \\
& Women & $7.00 \mathrm{EUR}$ & $10.00 \mathrm{EUR}$ & $5.00 \mathrm{EUR}$ \\
\hline \multirow{2}{*}{ IQR } & Men & $3.25 \mathrm{EUR}$ & $3.25 \mathrm{EUR}$ & $1.25 \mathrm{EUR}$ \\
& Women & $3.25 \mathrm{EUR}$ & $3.25 \mathrm{EUR}$ & $1.25 \mathrm{EUR}$ \\
\hline \hline
\end{tabular}

Source: Own calculations based on software AV-Win by Morgen \& Morgen GmbH, for exact specifications please refer to Appendix A. 10 years period certain annuity, results based on data from 28 companies. 
Table 2: Statistics on Estimated Monthly Pension Payments in the First Year

\begin{tabular}{llrrr}
\hline \hline & & Gender-specific & Unisex & Adjustment \\
\hline \multirow{2}{*}{ Mean } & Men & $102.48 \mathrm{EUR}$ & $95.03 \mathrm{EUR}$ & $-7.45 \mathrm{EUR}$ \\
& Women & $94.14 \mathrm{EUR}$ & $95.03 \mathrm{EUR}$ & $0.90 \mathrm{EUR}$ \\
\hline \multirow{2}{*}{ Max-Min } & Men & $21.00 \mathrm{EUR}$ & $19.00 \mathrm{EUR}$ & $11.00 \mathrm{EUR}$ \\
& Women & $21.00 \mathrm{EUR}$ & $19.00 \mathrm{EUR}$ & $12.00 \mathrm{EUR}$ \\
\hline \multirow{2}{*}{ IQR } & Men & $10.25 \mathrm{EUR}$ & $9.25 \mathrm{EUR}$ & $2.00 \mathrm{EUR}$ \\
& Women & $10.25 \mathrm{EUR}$ & $9.25 \mathrm{EUR}$ & $2.00 \mathrm{EUR}$ \\
\hline \hline
\end{tabular}

Source: Own calculations based on software AV-Win by Morgen \& Morgen GmbH, for exact specifications please refer to Appendix A. 10 years period certain annuity, results based on data from 28 companies.

Table 3: Mean Money's Worth Ratio of Full Pension Based on Own Contributions Only

\begin{tabular}{|c|c|c|c|}
\hline & & Gender-specific & Unisex \\
\hline \multirow[t]{2}{*}{ Men } & Population & 0.916 & 0.843 \\
\hline & Annuitants & 1.005 & 0.925 \\
\hline \multirow[t]{2}{*}{ Women } & Population & 0.950 & 0.951 \\
\hline & Annuitants & 1.029 & 1.030 \\
\hline
\end{tabular}

Source: Own calculations based on software AV-Win by Morgen \& Morgen GmbH, for exact specifications please refer to Appendix A. 10 years period certain annuity, results based on data from 28 companies.

Table 4: Expected Remaining Lifetime in Years of 65-year-old Persons in 2021

\begin{tabular}{lrr}
\hline \hline & Annuitants & Population \\
\hline Men & 22.60 & 19.69 \\
Women & 26.36 & 23.47 \\
\hline
\end{tabular}

Source: Own calculations based on mortality tables DAV2004R and abridged life tables 2002/2004. Period life tables are updated with the trend function supplied in DAV (2005a). The parameters are chosen at $T_{1}=1$ and $T_{2}=20$ as explained in Appendix A.2. 


\section{References}

Börsch-Supan, A., and C. B. Wilke (2004): "The German Public Pension System: How It Was, How It Will Be," NBER Working Paper No. 10525.

Buchmueller, T., and J. DiNardo (2002): "Did Community Rating Induce an Adverse Selection Death Spiral? Evidence from New York, Pennsylvania, and Connecticut," American Economic Review, 92(1), 280-294.

DAV (2005a): "Herleitung der DAV-Sterbetafel 2004 R für Rentenversicherungen," Blätter der Deutschen Gesellschaft für Versicherungs- und Finanzmathematik, 27(2), 199-314, Working Group on Mortality of Pensioners of the German Actuaries' Society.

(2005b): "Unisex-Rechnungsgrundlagen für Die Reservierung Von Riester-Produkten," Mimeo, Working Group on Biometric Calculations of the German Actuaries' Society.

Federal Statistical Office Germany (2006): "Aktuelle Sterbetafeln für Deutschland 2002/2004 (Mortality Tables for Germany 2002/2004," Available at http://destatis.de/.

Finkelstein, A., and J. Poterba (2004): "Adverse Selection in Insurance Markets: Policyholder Evidence from the U.K. Annuity Market," Journal of Political Economy, 112(1), 183-208.

Finkelstein, A., J. Poterba, and C. Rothschild (2006): "Redistribution by Insurance Market Regulation: Analyzing a Ban on Gender-Based Retirement Annuities," NBER Working Paper 12205.

Herring, B., and M. V. Pauly (2006): "The Effect of State Community Rating Regulations on Premiums and Coverage in the Individual Health Insurance Market," NBER Working Papers 12504, National Bureau of Economic Research, Inc.

James, E., and D. Vittas (2000): "Annuities Markets in Comparative Perspective: Do Consumers Get Their Money's Worth?," in OECD 2000 Private Pensions Conference. OECD, Paris.

Mitchell, O. S., and D. McCarthy (2002): "Annuities for an Ageing World," NBER Working Paper 9092.

Mitchell, O. S., J. M. Poterba, M. J. Warshawsky, and J. R. Brown (1999): "New Evidence on the Money's Worth of Individual Annuities," American Economic Review, 89(5), 1299-1318.

Post, T., H. Gründl, and H. Schmeiser (2006): "Portfolio Management and Retirement: What is the Best Arrangement for a Family?," Mimeo, Humboldt-Universität zu Berlin.

Simon, K. I. (2005): "Adverse selection in health insurance markets? Evidence from state small-group health insurance reforms," Journal of Public Economics, 89(9-10), 1865-1877.

von Gaudecker, H.-M., and C. Weber (2004): "Surprises in a Growing Market Niche: An Evaluation of the German Private Life Annuities Market," The Geneva Papers on Risk and Insurance, 29(3), 394-416. 


\section{Discussion Paper Series}

Mannheim Research Institute for the Economics of Aging Universität Mannheim

To order copies, please direct your request to the author of the title in question.

\begin{tabular}{|c|c|c|c|}
\hline Nr. & Autoren & Titel & Jahr \\
\hline $96-05$ & $\begin{array}{l}\text { Jorge Gonzalez- } \\
\text { Chapela }\end{array}$ & On Measuring Convergence in the Use of Time & 05 \\
\hline $97-05$ & $\begin{array}{l}\text { Christina Benita } \\
\text { Wilke }\end{array}$ & $\begin{array}{l}\text { Rates of Return of the German PAYG System - } \\
\text { How they can be measured and how they will } \\
\text { develop }\end{array}$ & 05 \\
\hline $98-05$ & Karsten Hank & $\begin{array}{l}\text { Spatial Proximity and Contacts between Elderly } \\
\text { Parents and Their Adult Children: A European } \\
\text { Comparison }\end{array}$ & 05 \\
\hline $99-05$ & Matthias Weiss & $\begin{array}{l}\text { On the Evolution of Wage Inequality in } \\
\text { Acemoglu's Model of Directed Technical Change }\end{array}$ & 05 \\
\hline $100-05$ & $\begin{array}{l}\text { Matthias Weiss } \\
\text { Alfred Garloff }\end{array}$ & $\begin{array}{l}\text { Skill Biased Technological Change and } \\
\text { Endogenous Benefits: The Dynamics of } \\
\text { Unemployment and Wage Inequality }\end{array}$ & 05 \\
\hline $101-06$ & $\begin{array}{l}\text { Melanie Lührmann } \\
\text { Matthias Weiss }\end{array}$ & $\begin{array}{l}\text { Market Work, Home Production, Consumer } \\
\text { Demand and Unemployment among the } \\
\text { Unskilled }\end{array}$ & 06 \\
\hline $102-06$ & \begin{tabular}{|l|} 
Hans-Martin von \\
Gaudecker \\
Rembrandt D. Scholz
\end{tabular} & Lifetime Earnings and Life Expectancy & 06 \\
\hline $103-06$ & \begin{tabular}{|l|} 
Dirk Krueger \\
Alexander Ludwig
\end{tabular} & $\begin{array}{l}\text { On the Consequences of Demographic Change } \\
\text { for Rates of Returns to Capital, and the } \\
\text { Distribution of Wealth and Welfare }\end{array}$ & 06 \\
\hline $104-06$ & $\begin{array}{l}\text { Karsten Hank, } \\
\text { Hendrik Jürges, } \\
\text { Jürgen Schupp, } \\
\text { Gert G. Wagner }\end{array}$ & $\begin{array}{l}\text { Die Messung der Greifkraft als objektives } \\
\text { Gesundheitsmaß in sozialwissenschaftlichen } \\
\text { Bevölkerungsumfragen: Erhebungsmethodische } \\
\text { und inhaltliche Befunde auf der Basis von } \\
\text { SHARE und SOEP }\end{array}$ & 06 \\
\hline $105-06$ & Hendrik Jürges & $\begin{array}{l}\text { True health vs. response styles: Exploring cross- } \\
\text { country differences in self-reported health }\end{array}$ & 06 \\
\hline $106-06$ & $\begin{array}{l}\text { Christina Benita } \\
\text { Wilke }\end{array}$ & $\begin{array}{l}\text { Die ökonomischen Auswirkungen des } \\
\text { demographischen Wandels in Bayern }\end{array}$ & 06 \\
\hline $107-06$ & Barbara Berkel & $\begin{array}{l}\text { Retirement Age and Preretirement in German } \\
\text { Administrative Data }\end{array}$ & 06 \\
\hline $108-06$ & $\begin{array}{l}\text { Hans-Martin von } \\
\text { Gaudecker } \\
\text { Carsten Weber }\end{array}$ & $\begin{array}{l}\text { Mandatory Unisex Policies and Annuity Pricing: } \\
\text { Quasi-Experimental Evidence from Germany }\end{array}$ & 06 \\
\hline
\end{tabular}

